\title{
POLITIK KEBIJAKAN PENDIDIKAN RESTRUKTURISASI MADRASAH ALIYAH KEAGAMAAN (MAK)
}

\author{
Magdalena \\ Fakultas Tarbiyah dan IImu Keguruan IAIN Padangsidimpuan \\ Jalan T. Rizal Nurdin KM. 4,5 Sihitang Padangsidimpuan \\ E-mail: magdalena_0374@yahoo.co.id
}

\begin{abstract}
Abstrak
Madrasah Aliyah Keagamaan (MAK) adalah lembaga pendidikan Islam yang memiliki bentuk yang sama dengan madrasah. Artikel ini menjelaskan politik kebijakan pendidikan pemerintah tentang MAK yang merestrukturisasinya untuk menjadi salah satu panutan bagi lembaga Islam. Ide ini diharapkan dapat membangun MAK yang telah mandeg. Fungsi MAK adalah untuk mewujudkan cita-cita Muslim untuk "tafaqquh fi al-din". Tujuan pendirian MAK di antaranya dapat menghasilkan intelektual yang memiliki pengetahuan dan sains yang memiliki karakteristik Islam untuk mencapai perdamaian dunia dan kehidupan akhirat. Tujuan penulisan artikel ini adalah untuk membahas pentingnya MAK untuk pengembangan intituti Islam.
\end{abstract}

\begin{abstract}
Madrasah Aliyah Keagamaan (MAK) is a islamic educational institution which has a same type with madrasah. This article explains the government politics of education to MAK which should restructure it to become one of role model for Islamic institution. This ide is hoped can build MAK that has died. The functions of MAK are to realize the ideals of muslims to "tafaqquh fi al-din". Some goals which should get dealing which the existence of MAK can product the intellectual who has a Islamic knowledge and saintific that has Islamic characteristics in order to achieve world peace and the life hereafter. The purpose of writing this article is to discuss the significance of MAK to the development of the Islamic intitutions.
\end{abstract}

Kata Kunci: MAK, lembaga pendidikan Islam, restukturisasi, tafaqquh $f i$ al-din. 


\section{Pendahuluan}

Sejarah perjalanan politik Islam Indonesia oleh para aktivis masa lalu telah memberikan citra politik Islam Indonesia selalu berada dalam orbit yang tidak menguntungkan, ${ }^{1}$ termasuk politik pendidikannya. Samsul Nizar mengutip pendapat Pickering bahwa penataan kebijakan politik pemerintahan suatu negara merupakan aspek yang penting dalam upaya menata sistem pendidikan Islam yang baik. ${ }^{2}$

Kepentingan politik pendidikan yang diusung dalam lembaga pendidikan madrasah bukan semata-mata mewakili identitas diri sebagai lembaga pendidikan Islam, namun juga mencakup identitas Islam dan umat Islam. Keberadaan madrasah sebagai refresentatif kepentingan politik umat Islam untuk menunjukkan identitas lembaga pendidikan Islam sekaligus identitas agama dan umat. Sebaliknya, ketiadaan madrasah diasumsikan sebagai bukan cuma kematian identitas lembaga pendidikan Islam, namun kematian agama dan umat pula.

Dalam masyarakat modern, pendidikan adalah komoditi politik yang sangat urgen. Pendidikan merupakan wilayah tanggungjawab pemerintah terbesar dibandingkan dengan bidang lainnya. Pendidikan publik secara politis dikelola dan dikontrol oleh pemerintah sehingga dapat berjalan sesuai dengan kepentingan politik pemerintah. Pendidikan yang baik tentu hasil kelola kepentingan politik pemerintah yang baik, dan sebaliknya. Tentu saja hal ini berimplikasi besar terhadap kredibilitas pemerintah di mata masyarakat. Kebijakan terhadap lembaga pendidikan di Negara Indonesia tercinta ini merupakan akumulasi kepentingan politik pemerintah Indonesia, termasuk politik kebijakan terhadap madrasah umumnya, dan Madrasah Aliyah Keagamaan (MAK) khususnya.

MAK sebagai 'pilot project' dalam Madrasah Aliyah yang telah ditutup sebelumnya diketahui sangat strategis sebagai wadah regenerasi tafaqquh fi ad-din sehingga terwujud pribadi yang berkarakter. Di samping

${ }^{1}$ Iswandar, Dekontruksi Pemikiran Islam Idealitas Nilai dan Realitas Empiris (Yogyakarta: Ar-Ruzz Media Press, 2003), hlm. 144.

2Samsul Nizar, Memperbincangkan Dinamika Intelektual dan Pemikiran HAMKA tentang Pendidikan Islam (Jakarta: Kencana, 2008), hlm. 190. 
itu, hal ini menimbulkan dampak luar biasa terhadap perguruan tinggi Islam dalam bentuk sangat berkurangnya input calon mahasiswa untuk jurusan dan program studi agama. ${ }^{3}$ Secara tidak langsung, dampak marginalisasi jurusan agama atau keterpinggiran ilmu-ilmu agama tidak dapat terelakkan.

Karenanya, peran ini harus didukung dan difasilitasi dengan adanya aturan kebijakan dalam sistem pendidikan Nasional. Tentu saja politik kebijakan ini sangat penting sebagai penentu wajah dan arah pendidikan Islam selanjutnya. Hal ini hanya dapat didekati dengan pendekatan politik pendidikan karena aturan pendidikan akan menentukan sistem pendidikan. Atau penutupan MAK masih menyisakan pertanyaan penting tentang kepentingan politik pemerintah yang ada di baliknya.

Jika masalah ini dibiarkan larut tanpa adanya solusi kemunculan kebijakan pendidikan yang mengaturnya, maka dimungkinkan madrasah mandul melahirkan generasi yang tangguh seperti yang diharapkan. Madrasah tidak lebih seperti sekolah umumnya lainnya tanpa diiringi dengan distingsi keagamaan yang berarti. Islam dalam defenisi madrasah hanya sebatas label sekolah berbasis Islam. Tulisan ini menegaskan pentingnya memunculkan kembali Madrasah Aliyah Keagamaan.

Karenanya, makalah ini disusun untuk membahas politik kebijakan restrukturisasi Madrasah Aliyah Keagamaan (MAK). Di dalamnya terdapat beberapa pembahasan yang dimulai dengan pendahuluan, eksistensi madrasah dalam sistem pendidikan Nasional, kebijakan pemerintah atas madrasah, politik kebijakan restrukturisasi MAK, implikasi kebijakan atas MAK, dan penutup.

\section{Eksistensi Madrasah dalam Sistem Pendidikan Nasional}

Eksistensi madrasah tidak dapat dipisahkan dari kesadaran masyarakat muslim akan pentingnya pendidikan, dari mulai inisiatif pendiriannya, tanah dan bangunan, fasilitas dan tenaga guru. Semuanya dilakukan oleh masyarakat secara swadaya baik oleh organisasi sosial keagamaan maupun yayasan-yayasan pendidikan Islam (Community

${ }^{3}$ Azyumardi Azra, Pendidikan Islam Tradisi dan Modernisasi di Tengah Tantangan Milenium III (Jakarta: Rawamangun, 2012), hlm. 101-102. 


\section{Magdalena}

Based Education).4 Madrasah berkembang dari masyarakat untuk masyarakat. Hal ini mengakibatkan secara kuantitas madrasah semakin bertambah, namun secara kualitas madrasah masih jauh dari kemajuan. ${ }^{5}$

Menurut catatan Sirozi, pendirian madrasah dilatarbelakangi oleh kondisi pendidikan pada saat awal abad ke-20 tersebut didominasi sistem pendidikan sekular yang dipadu dengan kepentingan colonial Belanda dan diselubungi dengan misi misionaris Kristen. Madrasah adalah bentuk konkret hasil reaksi pemimpin muslim modernis yang melawan sistem pendidikan sekular dengan sistem pendidikan madrasah. ${ }^{6}$ Kala itu, mereka berpandangan madrasah sebagai sebuah model lembaga pendidikan Islam yang menghilangkan implikasi dikotomis sekuler-agama yang mewarnai sistem pendidikan nasional dalam aspek proses dan karakteristik pendidikannya sebelumnya. ${ }^{7}$

Dengan demikian, jelas diketahui melalui konteks sejarah bahwa pendidikan madrasah merupakan model pendidikan yang diharapkan mampu melaksanakan sistem pendidikan nasional dengan memasukkan pengetahuan agama dan saintik secara terpadu. Sesuai dengan Undangundang Sistem Pendidikan Nasional 1989 dan 2003, tujuan peningkatan mutu pendidikan pada madrasah adalah agar mata pelajaran umum dari madrasah mencapai tingkat yang sama dengan mata pelajaran umum di sekolah umum yang setingkat. Menurut Ridlwan Nasir, hasil yang diharapkan adalah pertama, ijazah madrasah dapat mempunyai nilai yang sama dengan ijazah sekolah umum yang sederajat. Kedua, lulusan madrasah dapat melanjutkan ke sekolah umum setingkat lebih atas.

${ }^{4}$ Muhammad Syaifuddin, "Kebijakan Pemerintah tentang Yayasan dan Eksistensi Madrasah Swasta di Inondesia, Antara Solusi dan Permasalahannya", dalam Jurnal IImiah Keislaman A/ Fikra, Vol. 5 No. 1, Januari-Juni 2006, hlm. 90.

${ }^{5}$ Abdul Rahman Halim, "Aktualisasi Implementasi kebijakan Pendidikan pada Madrasah Swasta di Sulawesi Selatan", dalam Lentera Pendidikan, Vol. 11 No. 1 Juni 2008, hlm. 83-100.

6Muhammad Sirozi, Politik Pendidikan di Indonesia: Peran Tokoh-tokoh Islam dalam Penyusunan UU No. 2/1989, diterjemahkan oleh Lilian D. Tedjasudhana (Jakarta: INIS, 2004), hlm. 37.

7 lbid., hlm. 39. 
Ketiga, siswa madrasah dapat berpindah ke sekolah umum yang setingkat. 8

Secara tidak langsung, menurut Supiana implikasi kebijakan ini memberikan peluang bagi lulusan madrasah untuk melakukan mobilitas sosial dan vertikal yang selama ini terbatas pada lembaga-lembaga pendidikan tradisional seperti pesantren dan madrasah. Di sisi lain, hal ini membuka peluang kemungkinan lulusan madrasah untuk memasuki wilayah pekerjaan pada sektor modern. ${ }^{9}$

Momentum terbesar pada madrasah terjadi pada tahun 1975. Restrukturisasi madrasah menjadi sederajat dengan sekolah umum dimulai sejak kemunculan Surat Keputusan Bersama (SKB) tiga Menteri, Menteri Agama, Menteri Dalam Negeri, dan Menteri Pendidikan dan Kebudayaan Nomor 037/U/1975 dan 36 Tahun 1975 tentang Peningkatan Mutu Pendidikan Madrasah. Kemunculan aturan tersebut di atas secara prinsipil dilatarbelakangi oleh kepentingan untuk peningkatan mutu pendidikan madrasah sehingga tingkat kualitas pengetahuan saintik siswa madrasah dapat menyamai siswa sekolah umum yang sederajat.

Tentu saja ketimpangan tingkat pengetahuan agama dan umum terjadi di madrasah dikarenakan selama ini sebelum kemunculan aturan dalam SKB Tiga Menteri tersebut proporsi untuk kedua keilmuan tersebut adalah berbanding terbalik yaitu $70 \%$ pengetahuan agama dan $30 \%$ pengetahuan saintik. Akibatnya mutu pendidikan madrasah lebih rendah daripada sekolah umum lainnya yang sederajat bila ditilik dalam perspektif proporsi keilmuan. Hal ini dianggap persoalan besar dalam perspektif sistem pendidikan Nasional karena menghasilkan mutu lulusan yang berbeda.

Perkembangan lebih lanjut menunjukkan bahwa hasil SKB Tiga Menteri tetap menempatkan Iulusan madrasah di bawah standar sekolah

8M. Ridlwan Nasir, Mencari Tipologi Format Pendidikan Ideal Pondok Pesantren di Tengah Arus Perubahan (Yogyakarta: Pustaka Pelajar, 2005), hlm. 92, Samsul Nizar, Sejarah Pendidikan Islam (Jakarta: Kencana, 2009), hlm. 294.

9Supiana, Sistem Pendididkan Madrasah Unggulan (Balitbang Departemen Agama RI, 2008), hlm. 44. 


\section{Magdalena}

umum meskipun telah berjalan selama 20 tahun. Tentu saja dengan analisis sederhana, hal ini menunjukkan bahwa letak permasalahan tidak terdapat pada isi kurikulum. Bahkan diduga hal ini terkait dengan kebijakan anggaran madrasah yang masih $30 \%$ dari seluruh anggaran sekolah umum. Hal ini lebih patut dicurigai sebagai penyebab ketidaksamaan mutu lulusannya, bukan malah isi kurikulum.

Sehubungan dengan permasalahan tersebut, Departemen Agama merasakan keprihatinan tersebut dan mencoba kembali kepada sistem yang lama dengan proporsi pengetahuan agama lebih besar dua kali lipat dari pengetahuan saintik. Akhirnya gagasan tersebut diterima oleh pemerintah dengan kemunculan Madrasah Aliyah Program Khusus (MAPK) dengan maksud terbentuknya satu macam pendidikan umum dan satu macam pendidikan agama. ${ }^{10}$ Pada program khusus ini, proporsi bidang agama mencakup $70 \%$ dari keseluruhan muatan kurikulumnya. ${ }^{11}$

\section{Kebijakan Pemerintah atas Madrasah}

Secara historis, madrasah didirikan dengan didorong oleh keinginan untuk merealisasikan nilai-nilai ajaran Islam dalam sebuah sistem pendidikan nasional. Namun, seiring dengan perkembangan zaman, madrasah yang bersifat populis ini mengalamai modernisasi yang berlangsung terus-menerus. Tetapi tidak dapat dipungkiri bahwa modernisasi tersebut memiliki pergeseran paradigma pendidikan pada madrasah sedikit demi sedikit.

Pada awalnya, peran aktif politik pendidikan Pemerintah RI terhadap madrasah dapat dilihat dari adanya beberapa kebijakan pendidikannya. Nunu Ahmad dkk mencatat beberapa kebijakan madrasah antara lain:

1. Adanya rekomendasi dari Badan Pekerja KNIP melalui Pengumuman Nomor 5 Tahun 1945 tanggal 22 Desember 1945 kepada Pemerintah RI untuk memajukan madrasah. Meskipun pada prakteknya, pemerintah sendiri lebih mengutamakan pengembangan sistem

10/bid., hlm. 94-95.

${ }^{11}$ Maksum, Madrasah Sejarah dan Perkembangannya (Jakarta: Logos wacana IImu, 1999), hlm. 160. 
sekolah; sebuah model pendidikan warisan Kolonial Belanda daripada madrasah sebagaimana yang tertera dalam usulan tersebut.

2. Adanya usulan dari Panitia Penyelidik Pengajaran untuk menerbitkan Peraturan Menteri Agama RI Nomor 1 Tahun 1946 tentang Pemberian Subsidi Bantuan Terhadap Lembaga Pendidikan Islam, termasuk madrasah. Di samping itu, peraturan ini mengatur perbaikan kurikulum lembaga pendidikan Islam dengan memuat mata pelajaran umum seperti bahasa Indonesia, berhitung, sejarah, dan ilmu bumi.

3. Menteri Agama RI Fathurrahman Kafrawi mengadopsi kurikulum lembaga pendidikan di lingkungan Departemen Pendidikan dan Kebudayaan untuk dimasukkan ke dalam kurikulum lembaga pendidikan Islam pada tahun 1947.

4. Selaras dengan gagasan sebelumnya, terdapat upaya Menteri Agama RI K.H. Wahid Hasyim untuk mengintegrasikan dualisme sistem pendidikan pada tahun 1949 dengan cara memasukkan tujuh mata pelajaran umum di lingkungan madrasah.

5. Penerbitan Undang-undang Pendidikan Tahun 1950 yang mempersepsikan pendidikan sebagai institusi yang bersifat netral terhadap agama dan sekuler. ${ }^{12}$

6. Kemunculan gerakan Madrasah Wajib Belajar (MWB) pada 1958.

7. Penerbitan Keputusan Presiden Nomor 34 Tahun 1972 dan Instruksi Presiden Nomor 15 Tahun 1974 tentang Tanggung Jawab Pendidikan dan Latihan hanya Berada di bawah Departemen Pendidikan dan Kebudayaan.

8. Penerbitan Surat Keputusan Bersama (SKB) Tiga Menteri Tahun 1975 tentang Integrasi Madrasah ke dalam Sistem Pendidikan Nasional.

9. Kelanjutannya adalah lahirnya SKB Dua Menteri yang menyepakati dikembangkannya kurikulum inti dan kurikulum khusus.

10. Penerbitan Undang-undang Sistem Pendidikan Nasional Tahun 1989 yang menggagas posisi madrasah sejajar dengan sekolah umum dengan tambahan ciri khas keislaman.

12Arief Subhan, Lembaga Pendidikan Islam Indonesia Abad ke-20 Pergumulan antara Modernisasi dan Identitas (Jakarta: Kencana, 2012), hlm. 227. 


\section{Magdalena}

11. Terakhir, kemunculan Undang-undang Nomor 20 Tahun 2003 tentang Sistem Pendidikan Nasional, yang berupaya mengangkat derajat madrasah sama dengan sekolah dalam tataran legal formal. ${ }^{13}$

Melihat sejumlah kebijakan madrasah yang muncul mulai dari zaman kemerdekaan sampai masa orde baru bahkan masa kontemporer sekarang ini memunculkan stigma positif peran pemerintah dalam merumuskan sistem pendidikan Nasional. Namun, sederetan panjang kesan stigmatik negatif masyarakat terhadap madrasah sebagai "second class institution" tidak dapat dihilangkan begitu saja.

Pada kenyataannya, terdapat dua kesan masyarakat terhadap politik kebijakan pemerintah dalam modernisasi madrasah ini. Pertama, kesan masyarakat "mencurigai" regulasi pemerintah atas madrasah sebagai kooptasi pemerintah belaka atas sebagian otoritas rakyat yang tidak saja merugikan madrasah, bahkan menghilangkan kepentingan umat Islam. Bahkan terbentuk opini masyarakat political will pemerintah yang tidak sepenuh hati terhadap madrasah. ${ }^{14}$ Kedua, kesan "menyetujui" karena modernisasi madrasah dianggap sebagai upaya memeliharanya untuk tetap "survive" dan relevan dengan tuntutan masa depan. ${ }^{15}$

Meskipun pada awalnya pendirian madrasah beranjak dari latar belakang perlunya integrasi dalam keilmuan dalam proporsi yang berbeda. Madrasah yang pada awalnya diharapkan sebagai mesin yang mampu menghasilkan lulusan yang mendalami keilmuan agama selain keilmuan saintik. Hal ini dianggap sebagai sebuah "keteledoran" dalam sistem pendidikan secara Nasional saat ini, yang sebelumnya dianggap sebagai "win win solution" terhadap kondisi pendidikan saat itu. Akhirnya "keteledoran" tersebut perlu diperbaiki melalui kemunculan SKB Tiga Menteri tersebut pada masa berikutnya menuju kesempurnaan sistem pendidikan nasional.

${ }^{13}$ Nunu Ahmad an-Nahidl, dkk., Posisi Madrasah dalam Pandangan Masyarakat (Jakarta: Gaung Persada Press, 2007), hlm. 3-4.

${ }^{14}$ /bid., hlm. 5.

15 /bid., hlm. 4. 


\section{Politik Kebijakan Restrukturisasi Madrasah Aliyah Keagamaan}

Penting untuk diketahui bahwa kemunculan SKB Tiga Menteri tersebut dinilai sebagai upaya modernisasi madrasah untuk mampu mensejajarkan mutu pendidikannya dengan sekolah umum sederajat. Namun, di sisi lain SKB Tiga Menteri tersebut mampu memberhentikan kerja mesin madrasah dalam melahirkan lulusan yang bermutu ulama. Tentu saja hal ini dianggap sebagai kelemahan dalam sistem pendidikan Islam yang bertujuan untuk menghasilkan lulusan yang memiliki kepribadian muslim seperti yang diwakilkan melalui profil ulama.

Banyak kritik muncul dari kalangan tokoh pendidikan yang melihat bahwa lulusan madrasah sebagaimana yang diharapkan mampu tampil sebagai sosok ulama tidak mencapai target yang diinginkan. Bahkan banyak yang mengira bahwa lulusan madrasah adalah manusia yang memiliki pengetahuan serba tanggung atau setengah-setengah. Manusia yang tidak memahami pengetahuan agama dan pengetahuan saintik secara komprehensif. Hal ini pulalah yang menjadi alasan pemerintah untuk memodernisasi madrasah.

Sebagaimana dikutip oleh Tilaar, seorang pakar sosiologi, Gianfranco Poggi membagi kekuasaan atas tiga jenis, yaitu: (1) kekuasaan politik, (2) kekuasaan ekonomi, (3) kekuasaan normatif atau ideologis. ${ }^{16}$ Pemerintah Indonesia melalui kekuasaan normatif atau ideologisnya telah mempolakan sistem pendidikan Nasional dengan orientasi ideologi Pancasila sebagai nilai-nilai dasar pendidikan. ${ }^{17} \mathrm{Hal}$ ini terbukti dengan adanya ketiga Undang-undang Sistem Pendidikan Nasional (UUSPN) di Indonesia mulai UUSPN 1959, 1989, dan 2003.

Keseluruhan UUSPN tersebut diwarnai oleh ideologi Pancasila, sebagai bentuk pilihan idelogi bangsa Indonesia yang diwakili oleh pemimpin-pemimpin bangsa pada awal pembentukan Negara Indonesia. Dalam bingkai perundang-undangan secara sosiologis, pelaksanaan UUSPN tersebut diharapkan lebih baik dari sebelumnya, meskipun secara

16H.A.R. Tilaar, Kekuasaan dan Pendidikan Manajemen Pendidikan Nasional alam Pusaran Kekuasaan (Jakarta: Rineka Cipta, 2009), hIm. 133.

${ }^{17 / \text { bid., hlm. } 79 .}$ 


\section{Magdalena}

substansi, isi UUSPN tersebut mengarah kepada ideologi Pancasila tidak berubah, bahkan menuju kematangan.

Pembicaraan politik pendidikan tentu tidak terlepas dari pembicaraan berkenaan dengan pendidikan dan kekuasaan. Pilihan pendidikan dalam arti seluas-luasnya tentu merupakan pilihan atas kebutuhan yang paling mendesak dari masyarakat dalam peningkatan taraf hidupnya. Pilihan terhadap pendidikan merupakan respon terhadap kebutuhan masyarakat tersebut dalam konteks lingkungan dan waktu. Artinya, bahwa pilihan pendidikan bergantung kepada kondisi kebutuhan masyarakat pada saat itu.

Pada zaman globalisasi seperti saat ini, yang ditandai dengan perkembangan sains dan teknologi, tentu berimplikasi positif dan negatif terhadap pendidikan. Kerusakan moral dengan maraknya hedonisme, korupsi, dan penyelewengan seksual dihakimi merupakan bentuk ketidakberhasilan pendidikan. Menurut penulis, tentu saja kondisi ini memicu masyarakat untuk memilih pendidikan yang dapat menjadi alternatif pemecahan masalah di atas. Bentuk pendidikan madrasah diperkirakan menjadi alternatif pilihan masyarakat saat ini. Hal ini jelas terbukti dengan peningkatan angka partisipasi kasar masyarakat terhadap pendidikan madrasah. Animo masyarakat yang semakin positif terhadap agama sebagai sumber nilai abadi berimplikasi pada semakin tingginya minat masyarakat terhadap lembaga pendidikan agama, termasuk madrasah.

Dengan demikian, madrasah yang dianggap sama dengan sekolah umum plus bercirikan Islam perlu menata diri atau merestukturisasi diri. Dalam konteks ini, restrukturisasi madrasah dapat dilaksanakan melalui politik pendidikan Pemerintah Indonesia melalui kebijakan-kebijakannya. Dalam hal ini restrukturisasi madrasah dapat dilaksanakan melalui kemunculan MAK -sebelumnya MAPK- sebagai pilihan model pendidikan yang sarat dengan sumber nilai agama.

Kuat dugaan di satu sisi, melalui model pendidikan ini paling tidak muncul lulusan yang memiliki nilai-nilai agama yang kuat sebagai benteng terhadap kerusakan moral yang terjadi saat ini. Di sisi lain, melalui model pendidikan ini muncul manusia yang mampu menjadi ulama sebagai 
pewaris nabi dan penerus risalah kenabian sehingga masyarakat tetap terpelihara dari kerusakan moral.

Kekhawatiran terhadap hilangnya kekhasan pendidikan madrasah yang mengemban misi tafaqquh fi ad-din memunculkan kebutuhan untuk menyahuti adanya Madrasah Aliyah Keagamaan yang sebelumnya telah dikubur dalam kancah historis lembaga pendidikan Islam. Sejalan dengan kebutuhan tersebut, idealisme umat Islam untuk menjadikan madrasah sebagai identitas lembaga pendidikan Islam, jati diri Islam dan jati diri umat Islam. Karenanya, Madrasah Aliyah Keagamaan diharapkan mampu menjadi mercusuar perwujudan Islam sebagai ajaran, mewujudkan pribadi muslim kaffah, sekaligus lembaga pendidikan Islam yang berorientasi pada kepentingan nilai-nilai ajaran Islam sebagai visi misi lembaganya. Ekspektasi luhur ini mampu menjadi distigsi dan keunggulan komparatif lulusan madrasah dibandingkan sekolah umum. Seperti mengulang sejarah, ide brilian ini terlah disemai dan dilaksanakan oleh Munawir Sadzali ketika menggagas Madrasah Aliyah Program Keagamaan dulu. Gagasan ini diharapkan mampu melahirkan kembali lembaga pendidikan Madrasah Aliyah Keagamaan yang telah mati dulu.

Sekarang ini, setelah merdeka hampir 70 tahun dari kolonial Belanda, namun tampaknya politik kebijakan pendidikan pemerintah masih mewarisi politik kolonial yang diskriminatif. Politik kebijakan diskriminatif ini tampak pada lembaga pendidikan Islam madrasah. Tampak jelas berdasarkan kebijakan-kebijakan yang muncul tentang madrasah benarbenar mengadopsi beban ketakutan politis dan ideologis ala kolonial Belanda terdahulu.

Secara psikologis baik eksplisit maupun implisit, hubungan tidak romantis mewarnai relasi pemerintah dan umat Islam seperti beban psikologis yang dirasakan terhadap penjajah dahulu. Upaya mediasi yang berarti mengarah kepada harmonisasi kelembagaan sekolah yang dikembangkan pemerintah dengan pesantren dan madrasah yang didukung oleh umat Islam belum terarah. Termasuk keinginan untuk merestrukturisasi Madrasah Aliyah Keagamaan tersebut. 
Oleh karena itu, menurut penulis pemerintah melalui peran tokohtokoh pemimpin bangsa umumnya, dan pemimpin muslim khususnya harus bertanggung jawab untuk melahirkan aturan tentang pendidikan pada Madrasah Aliyah Keagamaan (MAK) ini. Karena, model pendidikan MAK ini masih dan perlu diadakan pada saat ini sehingga dapat direalisasikan.

Beberapa peta kelemahan pengelolaan MAK dapat ditemukan dalam beberapa aspek seperti organisasi dan kelembagaan, administrasi dan manajemen, kurikulum dan pembelajaran, ketenagaan, sarana dan prasarana, pembiayaan, kesiswaan, lingkungan, serta animo masyarakat. ${ }^{18}$ Artinya, kebijakan restrukturisasi MAK diharapkan mampu mengakomodasi seluruh kepentingan dalam bentuk solusi terhadap masalah di atas. Karenanya, sekali lagi diperlukan kebijakan MAK.

Kembali kepada UUSPN Tahun 2003, agar sejalan dengan nomenklatur yang ada, pengelolaan MAK mendapat peluang untuk dimunculkan sesuai dengan pasal 30. Peluang MAK dapat diintegrasikan dalam pendidikan keagamaan. Penyelenggaraan MAK ke depan lebih tepat jika diselenggarakan oleh Direktorat Pendidikan Diniyah dan Pondok Pesantren, bukan Direktorat Madrasah dan Pendidikan Agama yang telah berjalan selama ini. Namun demikian, penyelenggaraan MAK ini harus dipikirkan secara matang agar format MAK ke depan mampu menetralisir kebijakan dan kepentingan masyarakat banyak sehingga tidak menimbulkan korban social dan finansial yang lebih berat lagi. ${ }^{19}$

\section{Implikasi Kebijakan atas Madrasah Aliyah Keagamaan}

Meskipun MAK merupakan salah satu lembaga pendidikan Islam yang bersifat populis dengan dibuktikan peningkatan angka partisipasi kasar terhadap lembaga pendidikannya. Namun, kebijakan tentang "penguburan hidup-hidup MAK" amat disayangkan bagi sebagian besar masyarakat muslim Indonesia. Kebijakan ini dianggap kebijakan yang kurang bijak dengan beberapa alasan, yaitu:

18Nunu Ahmad an-Nadihl, Op.Cit., hlm. 78-91.

19/bid., hlm. 93. 
1. Kebijakan penutupan MAK dianggap merupakan refleksi dari penyelesaian masalah dengan jalan pintas, nir kesungguhan atau tidak mau susah alias "cari gampangnya saja", atau mungkin berbau arogansi.

2. Kebijakan tersebut sepertinya secara sengaja telah memotong sebagian misi utama Kementerian Agama sebagai pemegang dan penyambung tradisi pembelajaran tafaqquh fi ad-din yang sudah diembannya selama puluhan tahun sejak republik ini memproklamirkan kemerdekaannya.

3. Kebijakan ini membuat Kementerian Agama benar-benar terjebak dalam arus pendidikan yang lebih berorientasi materialistik. ${ }^{20}$

Keseluruhan alasan di atas menjadi argumentasi bijak untuk mereinkarnasi dan merestrukturisasi MAK sebagai sebuah program dalam Madrasah Aliyah dalam rangka memberikan nuansa distingsi dengan lembaga pendidikan lainnya. Kebutuhan ini dianggap mendesak bagi kepentingan umat Islam di Indonesia dengan berbagai alasan dalam multi perspektif.

Ketergesa-gesaan kemunculan kebijakan penutupan MAK dapat diperbaiki dengan ketersegeraan pembukan MAK kembali menjadi anak kandung dari lembaga pendidikan Islam di lingkungan Kementerian Agama. Bahkan jika tidak dihiraukan, hal ini memungkinkan menjadi preseden buruk bagi kiprah Kementerian Agama selanjutnya, terutama menyangkut masalah pendidikan agama. Kemunculan kebijakan baru atas restrukturisasi MAK diduga dapat memperbaiki kesalahan yang mungkin secara tak sengaja timbul dari ketergesaan kebijakan sebelumnya.

Keberadaan MAK sebagaimana lembaga pendidikan Islam lainnya dapat memacu peran lembaga pendidikan Islam menjadi semakin signifikan. Arief Efendi mencatat beberapa peran strategis lembaga pendidikan berbasis Islam di Indonesia seperti yang diharapkan dalam MAK dapat dilihat dari beberapa aspek, yaitu:

20Tim Penyusun, Revitalisasi Madrasah (Balitbang Departemen Agama RI, 2006), hlm. 5 . 


\section{Magdalena}

1. Aspek Pendidikan (Pedagogis)

Lembaga pendidikan Islam terbukti telah banyak melahirkan kaderkader pemimpin bangsa yang memiliki nilai nasionalisme dan wawasan keislaman yang tinggi.

2. Aspek Moral Spiritual

Lembaga pendidikan Islam bertujuan untuk memberikan dasar-dasar pemahaman keagamaan yang baik sekaligus pengamalannya. Hal ini nantinya menghantarkan peserta didik untuk memperoleh kehidupan yang baik di dunia dan akhirat

3. Aspek Sosio Kultural

Tidak dapat dipungkiri lembaga pendidikan Islam memberikan pengaruh yang signifikan terhadap corak dan karakter masyarakat. Persoalanpersoalan masyarakat hanya dapat diselesaikan oleh manusia yang memiliki karakter yang kuat seperti yang dihasilkan oleh lembaga pendidikan Islam. ${ }^{21}$

Madrasah dalam konteks mempersiapkan peserta didik menghadapi perubahan zaman memiliki peran yang amat penting. Keberhasilan madrasah dalam menyiapkan peserta didik dalam menghadapi tantangan masa depan yang lebih kompleks menghasilkan lulusan yang memiliki keunggulan kompetitif dan menjadi pemimpin umat dan bangsa yang ikut menentukan arah perkembangan bangsa ini. ${ }^{22}$

Hal ini sejalan dengan pendapat Ma'zumi dan Jakaria tentang eksistensi madrasah dalam membangun peradaban dunia, yaitu:

Similarly madrasah expected to be part of the center of excellence. Madrasah is an islamic educational institution or public institution that has Islamic characteristics. It become one of role model for Muslims. The functions and duties of madrasah are to realize the ideals of Muslims and to build a generation of people who believe, bookish knowledge and global perspective, in order to achieve world peace and

\footnotetext{
${ }^{21}$ Arief Efendi, "Peran Strategis Lembaga Pendidikan Berbasis Islam di Indonesia" dalam el-Tarbawi Jurnal Pendidikan Islam, No. 1 Vol. I 2008, hlm. 1-11.

22Mudhoffar Akhwan, "Pengembangan Madrasah sebagai Pendidikan untuk Semua, dalam el-Tarbawi Jurnal Pendidikan Islam, No. 1 Vol. I 2008, hlm. 41-54.
} 
the life hereafter. The purpose of writing this article is to discuss the contributions of madrasah to the development of the nation character. ${ }^{23}$

Beberapa pendapat di atas menguatkan pendapat penulis untuk melahirkan kembali Madrasah Aliyah Keagamaan mengingat peran strategis yang diembannya. Kelahiran kembali MAK ini akan mampu menghasilkan manusia yang memiliki karakter kuat yang mampu bersaing dalam dunia global, mengangkat derajat bangsa dalam kemajuan. Madrasah Aliyah Keagamaan memang layak untuk menjadi alternatif pendidikan untuk seluruh manusia tanpa memandang status dan golongan. Dalam konteks politik pendidikan, hal ini harus diperkuat dengan aturan yang mengakomodasi kepentingan Madrasah Aliyah Keagamaan.

Kebijakan tentang revitalisasi MAK diharapkan dapat menjadi bentuk perjuangan bagi pemimpin bangsa melalui politik pendidikan yang diperankannya. Kebijakan ini pula mampu mentransformasi MAK menjadi lembaga pendidikan atau satu program yang mampu tampil menjadi pioneer tafaqquh fi ad-din.

\section{Penutup}

Dalam peta pendidikan di Indonesia, madrasah memiliki akar yang kuat pada sendi-sendi nilai religius dan budaya bangsa. Bukan hal yang aneh, jika madrasah diasumsikan sebagai lembaga pendidikan Islam sebagai wujud entitas budaya bangsa asli Indonesia. Sejak awal pertumbuhannya, madrasah berdiri dengan mengibarkan kebutuhan dan kepentingan masyarakat untuk menuntut ilmu sehingga menjadi corong kontinuitas pemahaman dan pelestarian nilai ajaran agama Islam (tafaqquh fi ad-din) kepada generasi muslim penerus.

Terlepas dari perdebatan tentang marginalisasi ilmu dan jurusan agama di perguruan tinggi Islam, jelas madrasah termasuk MAK harus memiliki distingsi dengan sekolah lainnya. Hal ini harus didukung oleh kebijakan yang mengayomi kepentingan MAK. Tidak bisa lain, perlu adanya

23Ma'zumi dan Jakaria, "Contributions of Madrasah to The Development of The Nation Character", dalam International Journal Of Scientific \& Technology Research, Vol. 1, Issue 11, December 2012, hlm. 37-39. 


\section{Magdalena}

langkah-langkah terobosan baru untuk kembali memperkuat MAK sebagai tafaqquh fi ad-din. Jika tidak lembaga pendidikan Islam yaitu madrasah dihakimi sebagai pemutus pemasok tafaqquh fi ad-din. Konsekuensinya lembaga pendidikan Islam dikhawatirkan akan kehilangan identitas Islam dan umat Islam. Tentunya hal ini harus terus diperjuangkan dalam rangka peningkatan kualitas pendidikan Islam.

\section{Daftar Pustaka}

Abdul Rahman Halim, "Aktualisasi Implementasi kebijakan Pendidikan pada Madrasah Swasta di Sulawesi Selatan", dalam Lentera Pendidikan, Vol. 11 No. 1 Juni 2008.

Arief Efendi, "Peran Strategis Lembaga Pendidikan Berbasis Islam di Indonesia" dalam el-Tarbawi Jurnal Pendidikan Islam, No. 1 Vol. I 2008.

Arief Subhan, Lembaga Pendidikan Islam Indonesia Abad ke-20 Pergumulan antara Modernisasi dan Identitas, Jakarta: Kencana, 2012.

Azyumardi Azra, Pendidikan Islam Tradisi dan Modernisasi di Tengah Tantangan Milenium III, Jakarta: Rawamangun, 2012.

H.A.R. Tilaar, Kekuasaan dan Pendidikan Manajemen Pendidikan Nasional alam Pusaran Kekuasaan, Jakarta: Rineka Cipta, 2009.

Iswandar, Dekontruksi Pemikiran Islam Idealitas Nilai dan Realitas Empiris, Yogyakarta: Ar-Ruzz Media Press, 2003.

M. Ridlwan Nasir, Mencari Tipologi Format Pendidikan Ideal Pondok Pesantren di Tengah Arus Perubahan, Yogyakarta: Pustaka Pelajar, 2005.

Ma'zumi dan Jakaria, "Contributions of Madrasah to The Development of The Nation Character", dalam International Journal Of Scientific \& Technology Research, Vol. 1, Issue 11, December 2012.

Maksum, Madrasah Sejarah dan Perkembangannya, Jakarta: Logos wacana IImu, 1999.

Mudhoffar Akhwan, "Pengembangan Madrasah sebagai Pendidikan untuk Semua, dalam el-Tarbawi Jurnal Pendidikan Islam, No. 1 Vol. I 2008. 
Muhammad Sirozi, Politik Pendidikan di Indonesia: Peran Tokoh-tokoh Islam dalam Penyusunan UU No. 2/1989, diterjemahkan oleh Lilian D. Tedjasudhana, Jakarta: INIS, 2004.

Muhammad Syaifuddin, "Kebijakan Pemerintah tentang Yayasan dan Eksistensi Madrasah Swasta di Inondesia, Antara Solusi dan Permasalahannya", dalam Jurnal IImiah Keislaman Al Fikra, Vol. 5 No. 1, Januari-Juni 2006.

Nunu Ahmad an-Nahidl, dkk., Posisi Madrasah dalam Pandangan Masyarakat, Jakarta: Gaung Persada Press, 2007.

Samsul Nizal, Memperbincangkan Dinamika Intelektual dan Pemikiran HAMKA tentang Pendidikan Islam, Jakarta: Kencana, 2008.

Samsul Nizar, Sejarah Pendidikan Islam, Jakarta: Kencana, 2009.

Supiana, Sistem Pendididkan Madrasah Unggulan, Balitbang Departemen Agama RI, 2008.

Tim Penyusun, Revitalisasi Madrasah, Balitbang Departemen Agama RI, 2006. 